\title{
RANCANG BANGUN SISTEM DISTILASI SURYA TIPE PARABOLIC UNTUK MENURUNKAN KADAR SALINITAS AIR LAUT
}

\author{
Duma Pabiban¹, Mikael Namas², Kasimir Sarifudin
}

\begin{abstract}
Abstrak :
Tujuan dari pada penelitian ini adalah merancang model distilasi surya tipe para bolic untuk menurunkan kadar salinitas air laut serta mengetahui hubungan antara intensitas cahaya mata hari terfokus dengan temperatur air laut dalam wadah evaporasi pada sistem distilasi surya tipe parabolic.

Penelitian ini dilaksanakan di Laboratorium Fisika Politeknik Negeri Kupang selama 8 bulan. Metode penelitian dilakukan dengan beberapa tahapan antara lain merancang alat tipe parabolic dengan ukuran diameter $1,80 \mathrm{~cm}$ dan tinggi $1,66 \mathrm{~cm}$. permukaan parabolic dilapisi dengan kaca cermin datar berfungsi untuk memantulkan cahaya mata hari ke wadah evaporasi (wadah pemanas). Kegiatan penelitian dilakukan mulai dari jam 08.30 sampai dengan jam 14.30 Wita. Sampel yang digunakan dalam penelitian adalah air laut yang berasal dari pantai Oesapa Kodya Kupang Propinsis Nusa Tenggara Timur. Parameter yang di ukur dalam penelitian tersebut antara lain : intensitas cahaya, temperatur, hasil evaporasi (destilat). Rancangan penelitian dilakukan dengan perlakuan sampel air laut volume $500 \mathrm{ml} ; 750 \mathrm{ml} ; 1000 \mathrm{ml} ; 1250 \mathrm{ml} ; 1500 \mathrm{ml} ; 1750 \mathrm{ml}$ dan $2000 \mathrm{ml}$. Perlakuan sampel air laut dilakukan sebanyak 3 kali pengulangan.

Hasil penelitian menunjukkan bahwa terjadinya pemanasan dalam wadah evaporasi mulai dari jam 11.00-14.00 Wita dengan intensitas cahaya mata hari 680-700 W/m², pada temperatur $84,6^{\circ} \mathrm{C}-98^{\circ} \mathrm{C}$. Hubungan antara volume air laut dengan intensitas mata hari adalah signifikan $(\dot{\alpha}$ $=0,05 \leq \mathrm{p}=0,513) ;$ hubungan volume air laut dengan hasil distilat adalah sangat signifikan ( $\dot{\alpha}$ $=0,01 \leq \mathrm{p}=0,769$ ); sedangkan hubungan antara volume air laut dengan temperatur tidak signifikan $(\dot{\alpha}=0,05 \geq \mathrm{p}=-0,062)$. Hubungan hasil distilat dengan perlakuan air laut sangat signifikan (sangat nyata), tetapi tidak ada hubungan antara perlakuan air laut dengan temperatur.

Efisiensi distilasi secara keseluruhan diketahui bahwa efisiensi rata-rata adalah $\eta_{d}=72,42 \%$. Hal ini menunjukkan bahwa penurunan salinitas air laut setelah mengalami distilasi adalah sangat efisien $\left(71 \% \leq \eta_{d}=72,42 \% \leq 85 \%\right)$. Nilai rata-rata prosentase penurunan salinitas air laut dari perlakuan volume $500 \mathrm{ml}$ sampai dengan $2000 \mathrm{ml}$ adalah sebesar 87,06\%.
\end{abstract}

Kata Kunci : Distilasi; Tipe parabolic; Salinitas.

\section{PENDAHULUAN}

Wilayah Kota Kupang Propinsi Nusa Tenggara Timur yang memiliki daerah pesisir yang cukup panjang dan wilayah laut yang cukup luas yaitu 94,790 $\mathrm{km}^{2}$ sering mengalami kekurangan air. Ketersediaan air bersih merupakan barang langka dan merupakan masalah utama di daerah-daerah pesisir kota ini. Penopang ketersediaan air bersih di daerah pesisir kota ini adalah dengan mengkonsumsi air dari sumur, PDAM dan reverse osmosis yang sekarang sudah menjamur di tepi-tepi jalan. 


\section{Jurnal Ilmiah FLASH Volume 2 Nomor 2 Desember 2016}

Untuk mendapatkan air bersih guna memenuhi kebutuhan hidup baik untuk masak, minum, cuci maupun mandi, masyarakat harus mengeluarkan biaya yang tinggi, (Badan Pusat Statistik Kota Kupang, 2013).

Dengan meningkatnya permintaan terhadap air bersih dan semakin terbatasnya sumber daya air bersih di Kota Kupang, maka perlu adanya upaya untuk penyediaan air bersih yang cukup bagi kebutuhan hidup masyarakat terutama penduduk yang tinggal di daerah pesisir karena tidak dijangkau oleh distribusi air bersih dari PDAM Kupang. Masyarakat yang tinggal di pesisir terkadang membuat sumur sebagai sumber air, karena air tersebut memiliki rasa asin sehingga tidak bisa digunakan sebagai air minum.

Upaya yang dapat dilakukan untuk penyediaan air bersih adalah dengan memanfaatkan sumber air yang ada, salah satunya adalah air laut. Air laut merupakan air yang berasal dari laut, memiliki rasa asin dan memiliki kadar garam (salinitas) yang tinggi. Rata-rata air laut di lautan memiliki salinitas sebesar 35, hal ini berarti untuk setiap satu liter air laut, terdapat 35 gram garam yang terlarut di dalamnya (Alamsyah, 2007). Air dengan salinitas tersebut tentu tidak dapat dikonsumsi. Untuk dapat dimanfaatkan, maka air laut perlu diolah terlebih dahulu menjadi air tawar. Air tawar adalah air dengan kadar garam di bawah 0,5 ppt (Nanawi, 2001). Teknik penurunan atau pembuangan kadar garam yang biasa dilakukan adalah penyulingan (distilasi), pembekuan, demineralisasi, elektrodialisis (ionisasi), reverse osmosis dan desinfeksi ( Linsley dan Franzini, 1995).

Sesuai dengan letak geografis dan berdasarkan data klimatologi, kota Kupang merupakan daerah beriklim kering yang dipengaruhi oleh angin muson dengan musim hujan yang pendek, sekitar bulan Desember - Maret dengan suhu berkisar antara $20,16-31{ }^{\circ} \mathrm{C}$. Sedangkan musim kering yang panjang, sekitar bulan April November dengan suhu berkisar antara 29,1 33,4 ${ }^{\circ} \mathrm{C}$ (Badan Pusat Statistik Kota Kupang, 2013). Kondisi iklim kering tersebut tentu sangat berpotensi bagi masyarakat setempat.
Persediaan energi matahari yang sangat cukup setiap tahunnya memberi keuntungan kepada masyarakat untuk menggunakannya dalam memenuhi kebutuhan hidup sehari-hari. Sejauh ini, pemanfaatan sumber energi matahari yang paling banyak adalah untuk pemanas. Salah satunya adalah pemanas air.

Pemanas air menggunakan energi surya dapat disebut dengan sistem distilasi tenaga surya. Sistem distilasi tenaga surya merupakan serangkaian alat penyulingan sederhana, murah dan mudah dibuat. Prinsip dasar pengolahannya adalah menguapkan air, kemudian menampung air yang diembunkan, diharapkan kotorankotoran yang ada pada air baku tersebut akan terpisahkan, sehingga diperoleh hasil akhir berupa air bersih (Suhada, 1995). Yang mendasari penggunaan energi matahari di antaranya merupakan energi terbarukan (renewable energy), mudah didapat dan tidak membutuhkan biaya, ramah lingkungan dan mudah perawatannya. Energi matahari merupakan salah satu solusi yang menjajikan untuk menghemat biaya dalam jangka panjang.

Intensitas sinar matahari yang masuk ditentukan oleh posisi matahari terhadap kolektor. Peningkatan intensitas sinar matahari dapat dilakukan dengan cara memfokuskan sinar matahari. Kolektor berbentuk parabola, dapat mengfokuskan sinar matahari sehingga mampu memanaskan air secara maksimal (Kreith, 1991).

Berdasarkan uraian dan beberapa peneliti sebelumnya, maka perlu diadakan penelitian untuk melakukan pengolahan air laut menjadi air minum dengan judul : Model Distilasi Surya Type Parabolic Untuk Menurunkan Kadar Salinitas Air Laut. Keunggulan dari penelitian ini adalah penggunaan sistem distilasi surya tipe parabolic yang berfungsi memfokuskan cahaya matahari sehingga dapat meningkatkan intensitas cahaya matahari yang diserap oleh wadah penguapan untuk proses distilasi air laut.

Berdasarkan uraian latar belakang tersebut maka dirumuskan masalah dalam penelitian ini adalah :1) bagaimana merancang model distilasi surya tipe parabolic untuk menurunkan kadar 
salinitas air laut ?; 2) bagaimana hubungan antara intensitas cahaya matahari terfokus dengan temperatur air laut dalam wadah evaporasi pada sistem distilasi surya tipe parabolic?; 3) berapa besar efisiensi sistem distilasi surya tipe parabolic dalam menghasilkan distilat dari air laut? ; 4) berapa besar penurunan salinitas air laut setiap pada sistem distilasi surya tipe parabolic?

Tujuan dari pada penelitian ini adalah: 1) merancang model distilasi surya tipe parabolic untuk menurunkan kadar salinitas air laut; 2) untuk mengetahui hubungan antara intensitas cahaya matahari terfokus dengan temperatur air laut dalam wadah evaporasi pada sistem distilasi surya tipe parabolic; 3) untuk mengetahui berapa efisiensi sistem distilasi surya tipe parabolic dalam menghasilkan distilat dari air laut; 4) untuk mengetahui berapa besar penurunan salinitas air laut setiap pada sistem distilasi surya tipe parabolic.

Adapun target luaran yang hendak dicapai dalam jangka waktu 2 tahun yakni: 1) menjadikan produk (model distilasi surya tipe para bolic) untuk menurunkan kadar salinitas air laut sebagai bahan baku air minum; 2) menjadikan produk untuk dimanfaatkan bagi masyarakat yang tinggal di daerah pesisir pantai atau di daerah yang tidak mendapatkan air yang berasal dari PDAM; 3) menjadi bahan informasi tentang hubungan antara intensitas cahaya matahari terfokus dengan temperatur air laut dalam wadah penguapan dan jumlah distilat yang dihasilkan pada sistem distilasi surya tipe parabolic; 4) menjadi bahan informasi tentang hubungan antara volume air baku dalam wadah evaporasi dengan laju distilasi pada sistem distilasi surya tipe parabolic.

\section{TINJAUAN PUSTAKA}

\subsection{Pengertian Air}

Air adalah salah satu pembawa penyakit yang berasal dari tinja manusia. Supaya air dapat masuk ke tubuh manusia baik berupa minuman ataupun makanan tidak merupakan pembawa bibit penyakit, maka diperlukan pengolahan air yang baik, berasal dari sumber jaringan transmisi atau distribusi yang mutlak diperlukan untuk mencegah terjadinya kontak antara kotoran sebagai sumber penyakit dengan air yang sangat diperlukan. Peningkatan kualitas air minum dengan jalan mengadakan pengolahan terhadap air yang akan digunakan sebagai air minum sangat diperlukan, terutama apabila air tersebut berasal dari air permukaan. Pengolahan yang dimaksud bisa dimulai dari yang sangat sederhana sampai pada pengolahan yang mahir/ lengkap (Sutrisno dan Eni, 2006).

Air tawar adalah air dengan kadar garam di bawah 0,5 ppt (Nanawi, 2001). Menurut Peraturan Pemerintah Republik Indonesia Nomor 82 Tahun 2001 Tentang Pengendalian Kualitas Air dan Pengendalian Kualitas Pencemaran, Bab I Ketentuan Umum pasal 1, menyatakan bahwa : "Air tawar adalah semua air yang terdapat di atas dan di bawah permukaan tanah, kecuali air laut dan air fosil.", sedangkan menurut Undang-Udang RI No. 7 Tahun 2004 tentang Sumber Daya Air (Bab I, Pasal 1), butir 2 disebutkan bahwa "Air adalah semua air yang terdapat pada, di atas, ataupun di bawah permukaan tanah, termasuk dalam pengertian ini air permukaan, air tanah, air hujan, dan air laut yang berada di darat". Butir 3 menyebutkan "Air tanah adalah air yang terdapat dalam lapisan atau batuan di bawah permukaan tanah". Karakteristik kandungan dan sifat fisis air tawar sangat bergantung pada tempat sumber mata air itu berasal dan juga teknik pengolahan air tersebut.

Menurut Peraturan Menteri Kesehatan Republik Indonesia Nomor 492/MENKES/PER/ IV/2010 Tentang Persyaratan Kualitas Air Minum, Pasal 1 menyatakan bahwa : "Air minum adalah air yang melalui proses pengolahan atau tanpa proses pengolahan yang memenuhi syarat kesehatan dan dapat langsung diminum" dan batas maksimum salinitas yang diperbolehkan dalam air minum adalah sebesar $400 \mathrm{mg} / \mathrm{L}$ sama dengan $0,4 \mathrm{~g} / \mathrm{L}$ atau $0,4 \%$. 


\section{4 | Jurnal Ilmiah FLASH Volume 2 Nomor 2 Desember 2016}

\subsection{Air laut}

Air laut memiliki rasa asin karena mengandung senyawa garam murni $(\mathrm{NaCl})$ yang cukup tinggi. Menurut beberapa sumber penelitian, kadar garam murni air laut berkisar 3,0\% dari jumlah total keseluruhan air laut. Karena rasa air laut yang asin, untuk menjadikan air laut sebagai air minum diperlukan sebuah teknologi terapan untuk memfilter sekaligus distilasi (penyuliangan) air untuk menghilangkan kadar garam yang tinggi (Alamsyah, 2007).

Ciri paling khas pada air laut yang diketahui oleh semua orang ialah rasanya yang asin. Ini disebabkan karena di dalam air laut terlarut garam-garam yang paling utama adalah natrium klorida $(\mathrm{NaCl})$ yang sering disebut garam dapur. Selain $\mathrm{NaCl}$, di dalam air laut terdapat pula $\mathrm{MgCl}$, kalium, kalsium dan sebagainya.

\subsection{Salinitas}

Salinitas didefinisikan sebagai jumlah bahan padat yang terkandung dalam tiap kilogram air laut, dinyatakan dalam gram per kilogram atau perseribu (Sutika, 1989). Menurut Afrianto dan Liviawaty (1991), salinitas adalah persentase unsur khlorida yang terkandung di dalam 1 kilogram air laut. Salinitas adalah jumlah berat semua garam (dalam gram) yang terlarut dalam satu liter air, biasanya dinyatakan dengan satuan $\% o$ (permil, gram per liter) (Irianto, 2003).

Menurut Dahuri dkk. (2001), salinitas permukaan perairan Indonesia rata-rata berkisar antara $32-34 \%$. Selanjutnya ditambahkan oleh Sutika (1989), salinitas air laut pada umumnya berkisar $33-37 \%$ dan berubah-ubah berdasarkan waktu dan ruang.

\subsection{Distilasi}

Menurut Linsley dan Franzini (1995), distilasi adalah teknologi penyulingan air untuk mendapatkan air tawar dari air kotor atau dari air laut, yang prinsipnya adalah menguapkan air laut dengan cara dipanaskan, yang kemudian uap air tersebut diembunkan sehingga didapatkan air tawar. Sumber panas yang dipergunakan berasal dari energi yang beragam yakni minyak, gas, listrik, kayu bakar, surya atau matahari dan lain-lain.

Salvato (Hidayat, 2011), mengemukakan bahwa distilasi sangat berguna untuk konversi air laut menjadi air tawar. Konversi air laut menjadi air tawar dapat dilakukan dengan teknik distilasi panas buatan, distilasi tenaga surya, elektrodialisis, osmosis, gas hydration, freezing, dan lain-lain. Homig (Hidayat, 2011), menyatakan bahwa untuk pembuatan instalasi distilator yang terpenting adalah harus tidak korosif, murah, praktis dan awet.

Jenis dan macam distilasi sangat bervariasi, tetapi distilator yang lazim digunakan dapat dikelompokkan menjadi tiga jenis. Adapun jenis-jenis distilator dimaksud yaitu distilasi sederhana, distilasi fraksinasi dan distilasi uap. Distilasi sederhana adalah pemisahan suatu komponen yang perbedaan titik didih komponen tersebut relatif besar. Distilasi fraksinasi merupakan pemisahan suatu komponen yang perbedaan titik didih komponen tersebut tidak terlalu besar dan dilakukan dengan proses pemanasan. Distilasi uap adalah proses pemisahan dengan penguapan bahan baku yang dimasukan sampai dengan habis teruapkan. Setelah itu baru dipisahkan dengan corong pisah (Meyers, 1992).

Distilasi dapat diartikan sebagai suatu proses penguapan cairan, pendinginan uap yang dihasilkan dan pengumpulan kondensat pada suatu tempat atau wadah. Metode distilasi ini sangat berguna untuk memisahkan suatu campuran yang terdiri dari komponen-komponen dengan titik didih berbeda atau salah satu komponen tidak dapat diuapkan (Budiana dan Neolaka, 2008).

\subsection{Energi Matahari}

Energi adalah sesuatu yang bersifat abstrak yang sukar dibuktikan tetapi dapat dirasakan adanya dan energi bisa merupakan sesuatu kemampuan untuk melakukan kerja. Menurut thermodinamika pertama, energi bersifat kekal, 
tidak dapat diciptakan dan tidak dapat dimusnahkan, tetapi dapat dikonversi dari bentuk yang satu ke bentuk yang lain. Energi dikategorikan menjadi berbagai macam yaitu: energi mekanik, energi listrik, energi elektromagnetik, energi kimia, energi nuklir dan energi thermal atau energi panas ( Muhammad, 2008).

Energi panas matahari merupakan salah satu energi yang potensial untuk dikelola dan dikembangkan lebih lanjut sebagai sumber cadangan energi terutama bagi negara-negara yang terletak di daerah khatulistiwa termasuk Indonesia, dimana matahari bersinar sepanjang tahun. Ada beberapa cara pemanfaatan energi panas matahari yaitu antara lain pemanasan ruangan, penerangan ruangan, kompor matahari, pengeringan hasil pertanian, distilasi air kotor, pemanasan air, pembangkitan listrik (Lakitan, 2002).

Tenaga matahari pada dasarnya adalah sinar matahari yang merupakan radiasi elektromagnetik pada panjang gelombang yang tampak dan yang tidak tampak, yakni mencakup spektrum cahaya inframerah sampai dengan cahaya ultraviolet.

\subsection{Distilasi matahari tipe kolektor surya parabolic}

Jenis ini dirancang untuk aplikasi yang membutuhkan energi panas pada temperatur antara $100{ }^{\circ} \mathrm{C}-400{ }^{\circ} \mathrm{C}$. Kolektor surya jenis ini mampu memfokuskan energi radiasi cahaya matahari pada suatu receiver, sehingga dapat meningkatkan kuantitas energi panas yang diserap oleh absorber. Spesifikasi jenis ini dapat dikenali dari adanya komponen konsentrator yang terbuat dari material dengan transmisivitas tinggi. Agar cahaya matahari selalu dapat difokuskan terhadap tabung absorber, konsentrator harus dirotasi. Pergerakan ini disebut dengan tracking. Temperatur fluida melebihi $400{ }^{\circ} \mathrm{C}$ dapat dicapai pada sistem kolektor ini (Kreith, 1991).

Prinsip kerja dari kolektor tipe parabolic adalah pemfokusan panas yang diterima dari matahari pada suatu titik menggunakan sebuah cermin cekung besar berbentuk U sehingga didapatkan panas yang besar yang dapat digunakan untuk menggantikan panas dari kompor minyak atau kayu bakar. Cermin-cermin tersebut diatur mengarah sinar matahari dan memusatkan sinar matahari ke sebuah panci atau aquarium berisi air. Ketika sinar paralel dari matahari memenuhi cermin melengkung dengan sudut datang sama akan dipantulkan melalui titik yang sama yang disebut fokus. Sinar matahari mempunyai energi yang cukup untuk merebus air (Kreith, 1991). Bentuk distilasi mata hari type kolektor surya paraboloc tampak pada gambar 1.

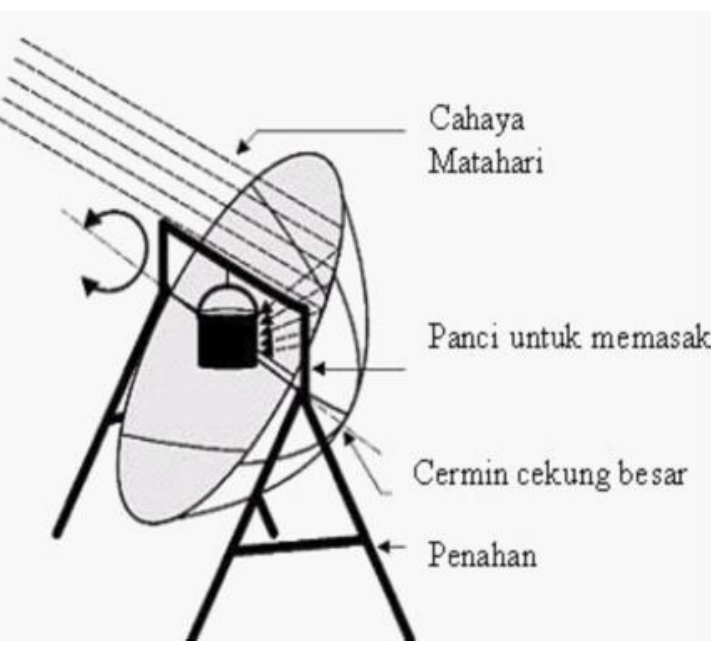

Gambar 1. Distilasi Matahari Tipe Kolektor Surya Parabolic (Kreith, 1991)

Untuk diameter cermin sebesar 1,3 meter konsentrator ini memberikan daya thermal sebesar 800 Watt pada panci. Dengan menggunakan konsentrator ini maka kebutuhan akan energi fosil dan energi listrik untuk memasak dapat dikurangi (Kreith, 1991).

Suhardi (2012), melakukan penelitian tentang menurunkan kesadahan air PAM menggunakan teknik distilasi matahari cahaya terfokus. Dalam penelitiannya, dilakukan peningkatan intensitas cahaya matahari dengan menggunakan kolektor kanal berbentuk seperti parabola silinder dengan ukuran panjang 240 $\mathrm{cm}$ dan lebar $120 \mathrm{~cm}$. Prinsip kerja alat tersebut adalah pantulan cahaya matahari difokuskan ke 
permukaan air dalam wadah distilator sehingga dapat memanaskan dan menguapkan air permukaan. Hasil penelitian menunjukkan bahwa kuantitas air yang dihasilkan pada proses ini tergantung pada lama waktu pemanasan. Dalam penelitian ini total kuantitas air yang dihasilkan sebanyak $470 \mathrm{~mL}$.

\subsection{Sistem Penguapan}

Penguapan (evaporation) adalah perubahan keadaan zat cair menjadi uap pada temperatur di bawah titik didih zat cair. Penguapan terjadi pada permukaan zat cair, beberapa molekul dengan energi kinetik yang paling besar melepaskan diri ke fasa gas. Akibatnya energi kinetik rata-rata molekul zat cair akan turun sehingga temperaturnya juga akan turun (Isaacs, 1994).

Menurut Lakitan (2002), laju evaporasi di Indonesia terjadi secara bervariasi tergantung ketinggian tempat dan waktu. Pada bulan Januari - April laju evaporasi masih rendah, puncaknya terjadi pada bulan Juni - September. Proses penguapan akan semakin baik apabila suhu air laut dalam ruangan evaporasi semakin tinggi. Semakin tinggi suhu suatu zat cair maka pergerakan molekul di dalamnya akan semakin cepat hingga terjadi tumbukan antar molekul yang akan menyebabkan semakin cepatnya proses perpindahan massa dari cairan ke gas yang disebut penguapan.

\section{METODE PENELITIAN}

\section{Jenis Penelitian}

Penelitian ini merupakan jenis penelitian tindakan dan penelitian eksperimen. Penelitian tindakan (action research), meliputi beberapa tahap yaitu pendekatan rancangan, tahap pembuatan alat dan tahap pengujian alat. Penelitian laboratorium yaitu untuk menentukan kadar salinitas air laut.

\section{Lokasi Kegiatan Penelitian}

Lokasi untuk melakukan kegiatan penelitian ini di Lab. Fisika Politeknik Negeri Kupang, sedangkan perancangan dan pengelasan dilaksanakan di Lab.Mesin Politeknik Negeri Kupang. Untuk pengujian secara kimia, biologi, dan salinitas air laut dilakukan di Lab. FKIP Jurusan Kimia Universitas Nusa Cendana Kupang.

\section{Waktu Penelitian}

Kegiatan penelitian ini berlangsung selama 8 bulan, yang terdiri dari 2 (dua) tahap yaitu: Tahap persiapan meliputi : Inventarisasi bahan dan peralatan; perancangan; pembuatan alat destilasi surya tipe parabolic; uji fungsi alat; pengambilan data; Tahap pelaksanaan meliputi :Persiapan Sampel; pengukuran salinitas air laut; proses distilasi air laut; pengukuran salinitas distilasi dan air laut sisa; pengumpulan data; analisis data; evaluasi dan pelaporan.

\section{Teknik Analisa Data}

Data hasil pengukuran panas matahari menggunakan alat actinograph dianalisis dengan menggunakan perangkat lunak program SPSS versi 17,0. Untuk mengetahui hubungan antara intensitas cahaya matahari dengan hasil distilasi, temperatur dalam wadah evaporasi, dan perlakuan air laut.

\section{HASIL DAN PEMBAHASAN}

\subsection{Deskripsi Singkat Model Sistem Distilasi Surya Type Parabolic}

Prinsip kerja dari model distilasi surya tipe parabolic adalah memfokuskan panas yang diterima dari matahari pada permukaan cermin kemudian dipantulkan kepada wadah (panci) yang berisi sampel air laut. Cermin-cermin tersebut direkatkan pada permukaan parabolic secara merata dan bersih agar hasil pantulan terhadap wadah lebih baik serta mempercepat pemanasan. Untuk mengarahkan parabolic dan memusatkan sinar matahari ke sebuah panci atau wadah yang berisi air laut membutuhkan ketelitian. Ketika sinar paralel dari matahari jatuh pada cermin melengkung dengan sudut datang sama akan dipantulkan melalui titik yang sama yang disebut fokus. Menurut Kreith (1991) bahwa Sinar matahari mempunyai energi yang 
cukup untuk merebus air dengan cara memfokuskan sinar matahari terhadap wadah. Bentuk model distilasi surya type parabolic tersebut adalah hasil modifikasi dari Kreith (1991), tampak pada gambar 2.

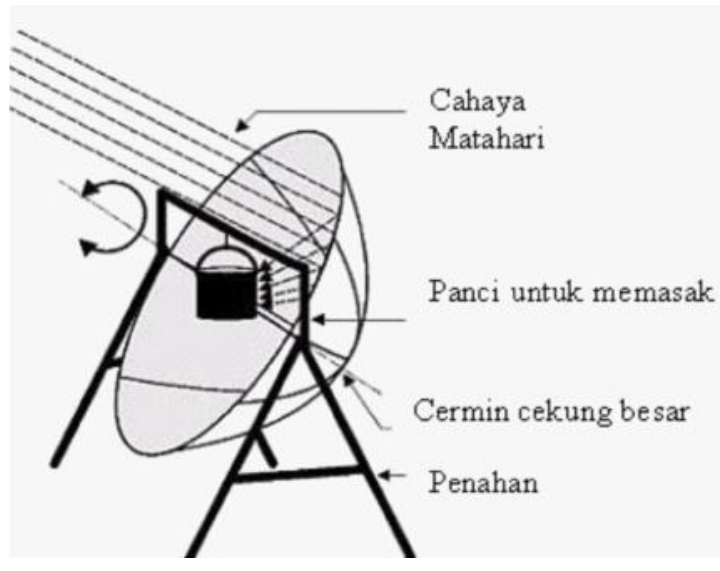

Gambar 2. Hasil Modifikasi gambar Distilasi Tipe Surya Parabolic (Kreith, 1991)
Spesifikasi gambar model distilasi surya type parabolic terdiri dari : a) tinggi : $166 \mathrm{CM}$, b) diameter parabolic: $186 \mathrm{~cm}$; C) volume wadah : $4000 \mathrm{ml}$, d) luas permukaan parabolic : 2,72 $\mathrm{m}^{2}$ wadah : e) luas permukaan wadah $\left(\mathrm{A}_{\mathrm{c}}=\right.$ $0,0394 \mathrm{~m}^{2}$.

\subsection{Hasil Penelitian}

Data hasil penelitian dianalisis sebagai berikut :

Hasil kegiatan penelitian ini dilakukan dengan tiga (3) kali perlakuan yaitu sampel air laut yang terdiri dari $500 \mathrm{ml} ; 750 \mathrm{ml} ; 1000 \mathrm{ml}$; $1250 \mathrm{ml} ; 1500 \mathrm{ml} ; 1750 \mathrm{ml}$ dan $2000 \mathrm{ml}$. Kegiatan penelitian menggunakan model surya tipe parabolic dengan cara menfokuskan sinar matahari yang jatuh pada permukaan kaca kemudian difokuskan terhadap wadah pemanas. Hasil selengkapnya mengenai pengukuran tersebut ditunjukkan pada tabel 1 .

Tabel 1. Data hasil pengukuran intensitas matahari, hasil distilasi, temperatur, mulai dari tanggal 22 Agustus sampai dengan 13 september 2016

\begin{tabular}{|c|c|c|c|c|c|c|}
\hline No. & $\mathrm{Tgl} / \mathrm{B} \ln /$ Tahun & $\begin{array}{l}\text { Perlakuan Air } \\
\text { Laut (ML) }\end{array}$ & $\begin{array}{l}\text { Intensitas Cahaya } \\
\text { Matahari (W/M2) }\end{array}$ & $\begin{array}{l}\text { Hasil Distilasi } \\
\text { (ML) }\end{array}$ & Temperatur & $\begin{array}{c}\text { Waktu } \\
\text { Epavorasi }\end{array}$ \\
\hline 1 & $22 / 08 / 2016$ & 500 & 670 & 30 & 70 & $12.00-14.00$ \\
\hline 2 & 05/09/2016 & 500 & 730 & 30 & 98 & $11.00-13.00$ \\
\hline 3 & $19 / 09 / 2016$ & 500 & 680 & 35 & 99 & $12.00-13.00$ \\
\hline 4 & $27 / 08 / 2016$ & 750 & 690 & 100 & 98 & $11.00-13.00$ \\
\hline 5 & $28 / 08 / 2016$ & 750 & 690 & 150 & 99 & $11.00-13.00$ \\
\hline 6 & $24 / 09 / 2016$ & 750 & 690 & 120 & 97 & $12.00-14.00$ \\
\hline 7 & $29 / 08 / 2016$ & 1000 & 670 & 180 & 98 & $11.00-14.00$ \\
\hline 8 & $30 / 08 / 2016$ & 1000 & 680 & 175 & 78 & $12.00-14.00$ \\
\hline 9 & $26 / 09 / 2016$ & 1000 & 690 & 200 & 78 & $13.00-14.00$ \\
\hline 10 & $31 / 08 / 2016$ & 1250 & 700 & 175 & 94 & $12.00-13.00$ \\
\hline 11 & $04 / 09 / 2016$ & 1250 & 710 & 150 & 78 & $12.00-13.00$ \\
\hline 12 & $16 / 09 / 2016$ & 1250 & 690 & 198 & 98 & $11.00-13.00$ \\
\hline 13 & $01 / 09 / 2016$ & 1500 & 690 & 220 & 90 & $11.00-14.00$ \\
\hline 14 & $17 / 09 / 2016$ & 1500 & 695 & 215 & 90 & $12.00-13.00$ \\
\hline 15 & $23 / 09 / 2016$ & 1500 & 680 & 200 & 80 & $11.00-13.00$ \\
\hline 16 & $02 / 09 / 2016$ & 1750 & 780 & 180 & 70 & $13.00-14.00$ \\
\hline 17 & $07 / 09 / 2016$ & 1750 & 720 & 157 & 90 & $11.00-13.00$ \\
\hline 18 & $09 / 09 / 2016$ & 1750 & 700 & 170 & 98 & $11.00-13.00$ \\
\hline 19 & $12 / 09 / 2016$ & 2000 & 700 & 250 & 98 & $11.00-13.00$ \\
\hline 20 & $13 / 09 / 2016$ & 2000 & 700 & 240 & 99 & $12.00-14.00$ \\
\hline 21 & $13 / 09 / 2016$ & 2000 & 700 & 200 & 97 & $12.00-14.00$ \\
\hline
\end{tabular}

Sumber : Data Primer, 2016 


\section{$\square$}

138

Jurnal Ilmiah FLASH Volume

Berdasarkan tabel 1 tersebut diketahui bahwa terjadinya pemanasan dalam wadah evaporasi mulai dari jam 11.00 - 14.00 Wita dengan intensitas cahaya matahari 680-700 W/ $\mathrm{m}^{2}$, pada temperatur $84,6^{\circ} \mathrm{C}-98^{\circ} \mathrm{C}$ dengan hasil distilat secara berurutan mulai dari perlakuan $500 \mathrm{ml}$ sampai dengan $2000 \mathrm{ml}$ secara berurutan $31,66 \mathrm{ml} ; 123,33 \mathrm{ml} ; 185 \mathrm{ml} ; 174,33 \mathrm{ml} ; 211,66$ $\mathrm{ml} ; 169 \mathrm{ml}$; dan $230 \mathrm{ml}$. Sedangkan rata-rata waktu yang dibutuhkan saat proses distilasi antara 1,33 jam sampai dengan 2,5 jam.

\subsection{Hasil Analisis Dan Pembahasan}

Data hasil penelitian dianalisis sebagai berikut :

\subsubsection{Rata-rata hasil pengukuran perlakuan air laut; temperatur; intensistas matahari dan hasil distilasi.}

Dalam kegiatan penelitian ini sampel air laut dilakukan dengan perlakuan sebanyak 3 kali mulai dari volume $500 \mathrm{ml} ; 750 \mathrm{ml} ; 1000 \mathrm{ml}$; $1250 \mathrm{ml} ; 1750 \mathrm{ml}$ dan $2000 \mathrm{ml}$ menggunakan gelas ukur. Untuk mengukur hasil intensitas matahari digunakan alat ukur actinograph; sedangkan hasil distilasi (air tawar) digunakan gelas ukur dan mencatat berapa lama waktu yang digunakan pada saat proses epavorasi, sedangkan untuk mengukur temperatur didalam wadah digunakan alat ukur thermometer digital. Hasil pengolahan data selengkapnya di lihat pada gambar 3.

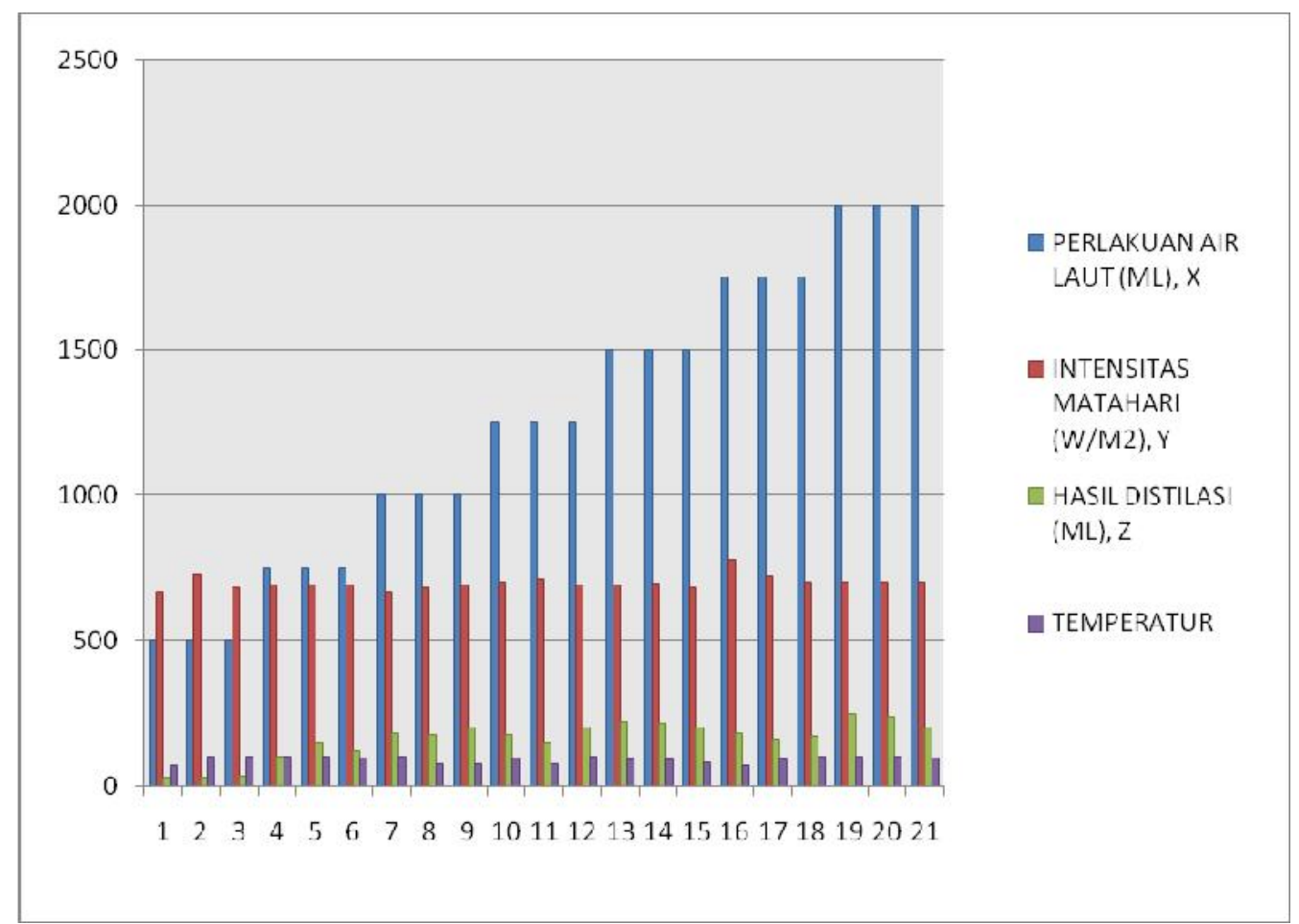

Gambar 3. Gambar rata-rata perlakuan air laut, intensitas matahari, hasil distilasi dan temperatur

Berdasarkan gambar 1 dan 2. diketahui bahwa pada perlakuan air laut dengan volume $500 \mathrm{ml}$ hasil rata-rata intensitas matahari 69,66 $\mathrm{w} / \mathrm{m}^{2}$, hasil distilat $31,66 \mathrm{ml}$, temperatur $89^{\circ} \mathrm{C}$.
Perlakuan dengan volume $750 \mathrm{ml}$ menghasil rata-rata intensitas matahari $690 \mathrm{~W} / \mathrm{m}^{2}$, hasil distilasi $123 \mathrm{ml}$ dan temperatur $89^{\circ} \mathrm{C}$. Perlakuan dengan volume $1000 \mathrm{ml}$ menghasil rata-rata 
intensitas matahari $680 \mathrm{~W} / \mathrm{m}^{2}$, hasil distilasi 185 $\mathrm{ml}$ dan temperatur $84,66^{\circ} \mathrm{C}$. Perlakuan dengan volume $1250 \mathrm{ml}$ menghasil rata-rata intensitas matahari $700 \mathrm{~W} / \mathrm{m}^{2}$, hasil distilasi $174,33 \mathrm{ml}$ dan temperatur $90^{\circ} \mathrm{C}$. Perlakuan dengan volume $1500 \mathrm{ml}$ menghasil rata-rata intensitas matahari $688,33 \mathrm{~W} / \mathrm{m}^{2}$, hasil distilasi $169 \mathrm{ml} \mathrm{dan}$ temperatur $86^{\circ} \mathrm{C}$. Perlakuan dengan volume $1750 \mathrm{ml}$ menghasil rata-rata intensitas matahari $700 \mathrm{~W} / \mathrm{m}^{2}$, hasil distilasi $230 \mathrm{ml}$ dan temperatur $98^{\circ} \mathrm{C}$. Dapat disimpulkan bahwa semakin besar volume perlakuan air laut tidak berbanding lurus dengan bertambahnya hasil distilasi, hal ini dipengaruhi oleh faktor cuaca seperti mendung, angin dan faktor ketelitian pada saat menfokuskan pantulan matahari terhadap wadah (pemanas).

\subsubsection{Hubungan antara perlakuan air laut, intensitas mata hari, hasil distilat dan temperatur}

Untuk mengetahui adanya hubungan antara perlakuan air laut dengan temperatur dalam wadah, serta intensitas mata hari, dan hasil distilat sesuai dengan hipotesis penelitian dari awal, maka dapat dilakukan proses komputasi dengan menggunakan komputer perangkat lunak Seri Program statistik (SPSS) Versi 17,0.

Uji korelasi antara perlakuan air laut, temperatur, intensitas mata hari dan hasil distilasi dapat diketahui dengan uji korelasi dengan Spearmans rho, hasil selengkapnya di tunjukkan pada tabel 2.

Tabel 2. Hasil korelasi antara air laut, intensitas matahari, distilasi dan temperatur

\begin{tabular}{|c|c|c|c|c|c|c|}
\hline & & & $\begin{array}{l}\text { P air } \\
\text { laut }\end{array}$ & Intensitas M & Distilasi & Temperatur \\
\hline \multirow[t]{12}{*}{ Spearman's rho } & \multirow[t]{3}{*}{ P_air_laut } & Correlation Coefficient & 1.000 & .513 & .769 & -.062 \\
\hline & & Sig. (2-tailed) & & .017 & .000 & .790 \\
\hline & & $\mathrm{N}$ & 21 & 21 & 21 & 21 \\
\hline & \multirow[t]{3}{*}{ Intensitas_M } & Correlation Coefficient & $.513^{\circ}$ & 1.000 & .095 & -.018 \\
\hline & & Sig. (2-tailed) & .017 & & .683 & .939 \\
\hline & & $\mathrm{N}$ & 21 & 21 & 21 & 21 \\
\hline & \multirow[t]{3}{*}{ Distilasi } & Correlation Coefficient & $.769^{*}$ & .095 & 1.000 & -.046 \\
\hline & & Sig. (2-tailed) & .000 & .683 & & .844 \\
\hline & & $\mathrm{N}$ & 21 & 21 & 21 & 21 \\
\hline & \multirow[t]{3}{*}{ Temperatur } & Correlation Coefficient & -.062 & -.018 & -.046 & 1.000 \\
\hline & & Sig. (2-tailed) & .790 & .939 & .844 & \\
\hline & & $\mathrm{N}$ & 21 & 21 & 21 & 21 \\
\hline
\end{tabular}

*. Correlation is significant at the 0.05 level (2-tailed).

${ }^{* *}$. Correlation is significant at the 0.01 level (2-tailed).

Berdasarkan hasil uji korelasi pada tabel 2. diketahui bahwa ada hubungan antara volume air laut dengan intensitas matahari adalah signifikan $(\dot{\alpha}=0,05 \leq p=0,513)$; hubungan volume air laut dengan hasil distilat adalah sangat signifikan $(\dot{\alpha}=0,01 \leq \mathrm{p}=0,769)$; sedangkan hubungan antara volume air laut dengan temperatur tidak signifikan ( $\dot{\alpha}=0,05 \geq$ $\mathrm{p}=-0,062)$. 


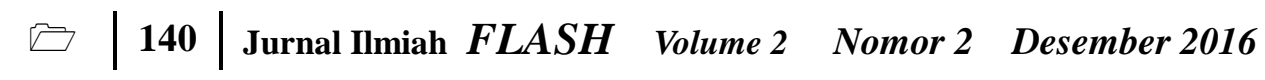

Hubungan antara intensistas matahari dengan distilasi signifikan $(\dot{\alpha}=0,05 \leq p=$ $0,095)$; intensitas matahari dengan temperatur tidak signifikan ( $\dot{\alpha}=0,05 \geq p=-0,018)$; distilasi dengan intensitas matahari hubungannya signifikan ( $\dot{\alpha}=0,05 ; \leq p=0,095)$; distilasi dengan temperatur hubungannya tidak signifikan $(\dot{\alpha}=0,05 \geq p=-0,046)$; Jadi dapat disimpulkan bahwa volume air laut dengan intensitas matahari adalah signifikan (ada hubungan), hubungan dengan hasil distilat dengan perlakuan air laut sangat signifikan (sangat nyata), tetapi tidak ada hubungan antara perlakuan air laut dengan temperatur.

Perhitungan efisiensi menggunakan data intensitas radiasi sinar matahari langsung dari tanggal 22 Agustus sampai dengan tanggal 13 September 2016, (data actinograph), dengan assumsi bahwa intensitas cahaya matahari luminasi surya tipe parabolic terfokus sama dengan intensitas cahaya matahari dikalikan dengan luas permukaan tipe surya type parabolic. Perhitungan efisiensi sistem distilasi mulai dari perlakuan volume air laut dari 500 $\mathrm{ml}$ sampai dengan $2000 \mathrm{ml}$ adalah sebagai berikut :

Sesuai dengan perhitungan efisiensi distilasi secara keseluruhan diketahui bahwa efisiensi rata-rata pada penelitian ini adalah $72,42 \%$. Nilai ini menunjukkan bahwa penurunan salinitas air laut setelah mengalami distilasi adalah sangat efisien $\left(71 \% \mathrm{~d}\right.$ " $\eta_{\mathrm{d}}=72,42 \% \mathrm{~d}$ " 85\%). Menurut Abdullah (2005), efisiensi model dalam menurunkan salinitas air laut adalah angka persentase penurunan salinitas air laut setelah mengalami distilasi pada model distilasi tersebut. Klasifikasinya sebagai berikut: a) $86 \%$ - 100\% (Sangat Efisien); b) $71 \%-85 \%$ (Efisien); c) $60 \%$ - 70\% (Cukup Efisien); d) $<60 \%$ (Tidak Efisien).

Bila dihitung secara kelompok bahwa pada volume $1000 \mathrm{ml}$ nilai efisiensi distilasi adalah efisien $\left(\eta_{d}=80,93 \%\right)$; pada perlakuan dengan volume $1250 \mathrm{ml}$, volume $1500 \mathrm{ml}$ dan $2000 \mathrm{ml}$ nilai efisiensi distilasi adalah sangat efisien $\left(\eta_{d}=\right.$ $\left.113 \% ; \eta_{d}=91,98 \% ; \eta_{d}=96,65 \%\right)$. Sedangkan pada perlakuan volume $500 \mathrm{ml}$, volume $750 \mathrm{ml}$ dan $1750 \mathrm{ml}$ nilai efisiensi adalah tidak efisien, secara berurutan adalah $\eta_{d}=16,95 \% ; \eta_{d}=$ $52,58 \% ; \eta_{d}=54,85 \%$.

Sehingga dengan demikian nilai rata-rata prosentase penurunan salinitas air laut dari pada sistem distilasi surya tipe parabolic mulai dari perlakuan volume $500 \mathrm{ml}$ sampai dengan 2000 $\mathrm{ml}$ adalah $87,06 \%$.

\section{KESIMPULAN DAN SARAN}

\subsection{Kesimpulan}

Berdasarkan hasil pembahasan pada bab sebelumnya, maka dapat ditarik beberapa kesimpulan sebagai berikut :

1.Hasil rancangan alat berupa model sistem distilasi surya tipe parabolic dengan ukuran diameter parabolic $186 \mathrm{~cm}$, tinggi $166 \mathrm{~cm}$, luas permukaan parabolic $2,72 \mathrm{~m}^{2}$.

2.Hubungan antara volume air laut dengan intensitas matahari adalah signifikan ( $\dot{\alpha}=0,05$ $\leq \mathrm{p}=0,513$ ); hubungan volume air laut dengan hasil distilat adalah sangat signifikan $(\dot{\alpha}=0,01$ $\leq \mathrm{p}=0,769)$; sedangkan hubungan antara volume air laut dengan temperatur tidak signifikan ( $\dot{\alpha}=0,05 \geq p=-0,062)$. Hubungan hasil distilat dengan perlakuan air laut sangat signifikan (sangat nyata), tetapi tidak ada hubungan antara perlakuan air laut dengan temperatur.

3.Efisiensi distilasi secara keseluruhan diketahui bahwa efisiensi rata-rata adalah $\eta_{d}=72,42 \%$. Hal ini menunjukkan bahwa penurunan salinitas air laut setelah mengalami distilasi adalah sangat efisien $\left(71 \% \leq \eta_{\mathrm{d}}=72,42 \% \leq\right.$ $85 \%)$.

4.Nilai rata-rata prosentase penurunan salinitas air laut dari perlakuan volume $500 \mathrm{ml}$ sampai dengan $2000 \mathrm{ml}$ adalah sebesar $87,06 \%$.

\subsection{Saran}

1.Untuk mendapatkan hasil distilat yang maksimal sangat membutuhkan ketelitian untuk memfokuskan intensitas sinar matahari pada bidang fokus (wadah pemanas). 
2.Kelemahan pada penelitian ini adalah adanya gangguan alam seperti mendung, hujan, dan angin karena dapat mengakibatkan berkurangnya hasil distilasi.

3.Penelitian tersebut perlu dilakukan penelitian lanjutan terutama untuk mengetahui hasil distilasi seperti air tawar dilakukan pengujian secara fisis, kimia dan biologi untuk menyesuaikan baku mutu air minum.

4.Model distilasi surya tipe parabolic tersebut masih difokuskan secara manual, karena itu perlu dilakukan penelitian lanjutan dengan menggunakan sistem kontrol dengan maksud untuk mengikuti pergerakan datangnya sinar matahari.

\section{DAFTAR PUSTAKA}

Alamsyah, S., 2007, Merakit Sendiri Alat Penjernih Air untuk Rumah Tangga, PT. Kawan Pustaka, Jakarta.

Badan Pusat Statistik Indonesia, 2013, Perkembangan Beberapa Indikator Utama Sosial-Ekonomi Indonesia, Badan Pusat Statistik, Jakarta.

Badan Pusat Statistik Kota Kupang, 2013, Profil Kesehatan Kota Kupang, Badan Pusat Statistik, Kupang.

Budiana, I.G.M.N. dan Neolaka, Y., 2008, DasarDasar Pemisahan, Universitas Nusa Cendana, Kupang.
Hidayat, R.R., 2011, Rancang Bangun Alat Pemisah Garam dan Air Tawar dengan Menggunakan Energi Matahari, Skripsi, Institut Pertanian Bogor, Bogor.

Irianto, A., 2003, Probiotik Akuakultur, Gadjah Mada University Press, Jogjakarta.

Kreith, F., 1991, Prinsip-Prinsip Perpindahan Panas, diterjemahkan oleh Arko Prijono, Erlangga, Jakarta.

Lakitan, B., 2002, Dasar-Dasar Klimatologi, PT Raja Grafindo Persada, Jakarta.

Linsley, R.K. dan Franzini, J.B., 1995, Teknik Sumber Daya Air, Erlangga, Jakarta.

Meyers, R.A., 1992, Encyclopedia of Physical Science and Technology, 2nd edition Volume 5, Academic press, New York.

Muhammad, E.W., 2008, Membuat Kompor Tenaga Matahari, artikel diambil dari http:/ /www.kamase.org/?p=519.

Peraturan Menteri Kesehatan Republik Indonesia Nomor 416/Menkes/Per/IX/1990 Tentang Syarat-Syarat dan Pengawasan Kualitas Air Minum, Depkes RI, Jakarta.

Peraturan Menteri Kesehatan Republik Indonesia Nomor 492/MENKES/PER/IV/ 2010 Tentang Persyaratan Kualitas Air Minum, Kementerian Kesehatan Republik Indonesia, Jakarta.

Soetrisno, 2004, Teknik Sumber Daya Air, Erlangga, Jakarta. 